\title{
Impact of Cluster Ions and Air Pollution on Human Health
}

\author{
Andris Skromulis \\ Rezekne Academy of Technologies, \\ Faculty of Engineering \\ Geotechnical and Eco-Industrial \\ Research Institute \\ Rezekne, Latvia \\ andris.skromulis@inbox.lv
}

\begin{abstract}
Maximum permissible concentration of polluting substances in the atmospheric air is defined in the laws and regulations of many countries. The concentration of cluster ions from 400 to 3000 ions per $\mathrm{m}^{3}$ is generally considered to be appropriate for human health. The author of this article analyses potential cases when air enrichment with air ions could enhance air purification and influence favourably human health. The author also describes possible adverse effects when air ionisation can increase the harmful impact on human body, especially in situations when the concentration of polluting substances exceeds the maximum permissible level.
\end{abstract}

Keywords - air ions, air pollution, human health.

\section{INTRODUCTION}

Air pollution is the main reason of many respiratory tract diseases and even deaths [1]. Air pollution increases the risk of respiratory diseases, such as asthma, respiratory infections, and chronic obstructive pulmonary disease, in children and adults. Maternal exposure to air pollutants mediates both short-term and long-term effects on the respiratory system. [2] Air pollution has many negative health effects on the general population, especially children, individuals with underlying chronic disease and the elderly [3]. Globally, seven million deaths were attributable to the joint effects of household and ambient air pollution. People with chronic respiratory diseases such as chronic obstructive pulmonary disease and asthma are especially vulnerable to the detrimental effects of air pollutants [4]. The problem of air pollution affects not only populated big cities, but it is also becoming more acute in smaller settlements.

It is a widespread belief nowadays that people are spending more time indoors for both work and leisure needs. Deterioration of outdoor air quality will inevitably lead to a deterioration of indoor air quality, as in many cases the quality of outdoor and indoor air is strongly correlated [5]. Indoor pollutants are different from those in the ambient air, although most of them are the same. Nevertheless, indoor air contains all the same pollutants as in the outdoor air, but the concentrations are different, usually lower. Besides the same pollutants as in the outdoor air, there are some other components in the indoor air which come from inside the building. The major sources include combustion of solid fuels indoors, tobacco smoking, emissions from construction materials and furnishings, and poor ventilation. [3],[6].

In order to fight against indoor air pollution, various air purification devices are available on the market. Many of them are based on the principle of air ionisation. Adding a charge to the pollution particles, including PM 10, promotes their formation into larger aggregates and sedimentation by the effect of gravity. Quite good results are achieved when purifying indoor air from cigarette smoke that mainly create PM 10 with a positive charge. Air enrichment with negative light air ions indoors provides good air purification results [7]. Studies on the interactions between air ions and indoor air pollution with aerosols are described in many publications, e.g. Priimann, 1984 [8], and the use of air ionisation technologies for purifying indoor air from fine aerosols is also quite popular (e.g. Shiue, 2011 [9]). Air ion therapy is even used to improve human health and well-being, cure burns, injuries and various diseases [10].

However, there are some problems in this area, for example, artificial air ionisers contribute to increased ozone concentrations indoors, which can considerably exceed levels favourable for humans [11]. Air ionisation is also used in airtight rooms where people are present, such as submarines and space ships, but the air there is always chemically cleaned too, for example by means of a special sorbents or electric membranes [12].

The content of both positive and negative air ions in the air has a significant impact on physiological processes in the human body, thus affecting the state of human health, mental and physical capacity, and well-being. Knowledge gained through scientific research about the role of air ion concentration in ensuring optimal human performance (e.g. Reinet, 1983; Hawkins, Barker, 1978; Hawkins, 1981) has already been incorporated into the national legislation of several states [13], [14], [15].

On 16 June 2003, sanitary and epidemiological rules and regulations "Hygienic Requirements for the Air-Ion Level of Industrial and Public Facilities SanPin 2.2.4 
1294-03 entered into force in the Russian Federation. According to these Requirements, optimal concentration of light negative ions amounts to $3000-5000$, while concentration of positive ions should be half as much [16].

Similar legislation has been adopted in Ukraine and Belarus. "SanPiN 2.2.4 1294-03" defines requirements for air ion content in spaces where, for various reasons, air ion concentration may not comply with the levels appropriate for human body. Environment favourable for human living should correspond to the following requirements: air ion concentration should be from 400 ions $\mathrm{cm}^{-3}$ to 50,000 ions $\mathrm{m}^{-3}$, while the value of unipolarity coefficient should be within $0.4 \leq \mathrm{K} \leq 1.0$, i.e. the concentration of negative air ions should be at least equal to or greater than the concentration of the positive ones.

Besides chemical and physical air pollution, the concentration of air ions and unipolarity coefficient $K$ creates an unexplored and undervalued impact on human health. Air ionisation, if $K \geq 1$, in combination with air polluting gases, aerosols and dust, is an additional factor adversely affecting human health and well-being. Under intense air pollution conditions, as a result of chemical ion transformations, a large amount of heavy air ions may occur and have a pronounced negative impact on human health. If the molecules of polluting gases are ionised, they have a stronger negative effect on the nature and on human body.

\section{MATERIALS AND METHODS}

The author of this article uses and further analyses data on concentrations of light ions and on chemical and physical parameters of the air, as reflected in the doctoral thesis "Impact of Anthropogenic Pollution on Air Ion Concentration" [17]. Concentrations of light air ions, i.e. cluster ions, were measured using a bipolar light air ion counter "Sapfir-3M" whose structure and operation is described in one of the literature sources [18]. The article provides analysis of data available in literature sources concerning the effects of air ions and air pollution on human health.

\section{RESULTS AND DISCUSSION}

From the point of view of the protection of human health, it is very important to understand the combined impact of air ion concentration and various air pollution components on the body. According to many studies, including those mentioned above [13], [15], air ions, in appropriate proportions and required concentrations, are able to compensate for the negative symptoms caused by air pollution. Light air ion therapy is used in the treatment of respiratory and pulmonary diseases, hypertension, tachycardia, excessive nervous excitability, spasms, etc. This suggests that there is an area where the beneficial or curative impact of air ions on the body can compensate for the negative effects of pollution. For example, increased $\mathrm{CO}_{2}$ concentration causes accelerated pulse, breathing and sweating, but these problems can theoretically be compensated by an appropriate increase in the concentration of light air ions.

On the other hand, ionisation as such can increase the harmful effects of pollutants, because, by entering the body in an ionised state, the harmful substance enters the metabolic process faster and more efficiently. The toxic effects of pollutants, both aerosols and gases in ionised state, may increase from a few percent up to several times depending on the nature and degree of ionisation of the substance [19], e.g. toxicity of manganese dioxide aerosols in ionised state increases several times [20]. By studying the harmful impact of vanadium oxides on the body, it has been found that bipolarly ionised aerosols are less harmful than the unipolarly ionised ones, besides negative heavy ions are not as harmful to the body as positive ions [20]. It is fairly safe to say that air ionisation has a positive effect if concentrations of pollutants do not exceed the maximum permissible concentration (MPC). Otherwise, formation of heavy aerosol ions at high concentrations is encouraged. For example, in order to maintain the required air ion concentration in classrooms by using artificial ionisation, the total concentration of aerosol particles (PM 10) in indoor premises should not exceed $0.1 \mathrm{mg} / \mathrm{m}^{3}$, otherwise the generated light air ions, coming in contact with PM 10, will become heavy and harmful to the students' health [19]. Measuring the concentration of aerosols PM 10 also does not directly demonstrate the presence of smaller aerosol fractions in the air, because heavy air ions are formed primarily from aerosol particles of 10 to $100 \mathrm{~nm}$ (the so-called "Aitken mode"), but it has been proven that aerosol fractions of various sizes originated from anthropogenic pollution correlate with each other well enough [21] to assume that smaller fractions are also present in the air after having measured only the concentration of larger particles. It has been found that, when the concentration of aerosols of an average size of $10 \mathrm{~nm}$ in the indoor air amounts to $0.1 \mathrm{mg} \cdot \mathrm{m}^{-3}$, the concentration of light air ions is very close to zero, while in the indoor air where tobacco smoke with particle size from 10 to $100 \mathrm{~nm}$ reaches $0.1 \mathrm{mg} \cdot \mathrm{m}^{-3}$, the concentration of heavy ions is $10^{5}-10^{6} \mathrm{~cm}^{-3}$, which is considered to be harmful to human health [22].

Due to the lack of convincing data on MPCs of heavy air ions for the protection of human health and because of the fact that they are not administratively standardised, it is difficult to determine the concentration threshold beyond which a negative impact begins. Heavy air ions are always present in nature because they are natural products of cluster ion ageing. Basing on long-term measurements performed in areas free from anthropogenic pollution, 1200 heavy air ions $\mathrm{cm}^{-3}$ [23] can be used as background concentration. It cannot be stated that exceeding this concentration has negative consequences, but it can be assumed that heavy ions at the background concentration level do not have any effect on human health. Chemical composition of heavy air ions is another factor that requires further research, because the negative health effects significantly depend on it.

Nowadays, many different indoor air ionisation 
devices are offered on the market, and their advertising usually emphasises the positive impact of air ions on human well-being, but practically none of them provides for simultaneous control of air ion concentration in indoors. Basing on a previous study [17], [24] it can be concluded that air ion concentration of in the indoor air tends to be variable under the influence of various chemical and physical factors; besides both the level of air ion concentration and unipolarity coefficient are most often in the range that is not favourable to human health and wellness, therefore, in order to improve the air quality, it is recommended to use air ionisers that increase and stabilise air ion concentrations and prevent their natural, often chaotic fluctuations.

TABLE I IMPACT OF VARIOUS COMBINATIONS INVOLVING AIR IONISATION AND CHEMICAL / PHYSICAL POLLUTION ON HUMAN BODY

\begin{tabular}{|c|c|c|c|c|}
\hline No. & $\begin{array}{c}\text { Ionisation degree (clus- } \\
\text { ter ions)* }\end{array}$ & $\begin{array}{c}\text { Degree of chemical pol- } \\
\text { lution, basically } \\
\mathrm{CO}, \mathrm{NO}_{\mathrm{X}}, \mathrm{SO}_{2}\end{array}$ & $\begin{array}{l}\text { Air ion concentration, } \\
\text { including PM } 10\end{array}$ & Impact on body \\
\hline 1 & Optimal & No & No & Optimally favourable \\
\hline 2 & Increased & No & No & Curative impact of air ions \\
\hline 3 & Very high & No & No & Harmful impact of increased ionisation \\
\hline 4 & Very low or non-existent & No & No & Harmful impact of deionised environment \\
\hline 5 & Very low or non-existent & Exceeds the MPC & Does not exceed the MPC & $\begin{array}{c}\text { Harmful impact of chemical pollution and deion- } \\
\text { isation }\end{array}$ \\
\hline 6 & Very low or non-existent & Does not exceed the MPC & Exceeds the MPC & $\begin{array}{l}\text { Harmful impact of aerosol pollution and deioni- } \\
\text { sation }\end{array}$ \\
\hline 7 & Very low or non-existent & Exceeds the MPC & Exceeds the MPC & $\begin{array}{c}\text { Total harmful impact of chemical pollution, } \\
\text { deionisation and aerosols }\end{array}$ \\
\hline 8 & Optimal or increased & Does not exceed the MPC & No & $\begin{array}{c}\text { Partial compensation of the negative impact of } \\
\text { chemical pollution }\end{array}$ \\
\hline 9 & Optimal or increased & No & Does not exceed the MPC & $\begin{array}{c}\text { Partial air purification from aerosols - favourable } \\
\text { impact }\end{array}$ \\
\hline 10 & Optimal or increased & Does not exceed the MPC & Does not exceed the MPC & $\begin{array}{l}\text { Partial compensation of the negative impact of } \\
\text { chemical and aerosol pollution }\end{array}$ \\
\hline 11 & Optimal or increased & Exceeds the MPC & Does not exceed the MPC & $\begin{array}{l}\text { Additional negative impact of partially ionised } \\
\text { pollution }\end{array}$ \\
\hline 12 & Optimal or increased & Does not exceed the MPC & Exceeds the MPC & $\begin{array}{c}\text { Formation of heavy air ions, partially negative } \\
\text { impact }\end{array}$ \\
\hline 13 & Optimal or increased & Exceeds the MPC & Exceeds the MPC & $\begin{array}{c}\text { Negative impact of ionised pollution and heavy } \\
\text { ions }\end{array}$ \\
\hline 14 & Very high & Exceeds the MPC & Exceeds the MPC & $\begin{array}{l}\text { Strong negative impact of increased ionisation, } \\
\text { heavy air ions and ionised pollution }\end{array}$ \\
\hline
\end{tabular}

At the same time, there is a need for a daily control of the level of air ion concentration and for regulation of ionisation intensity to keep it within the required limits, because performance of various electronic devices in offices can change the level of air ion concentration, for example, intensive use of a copier significantly increases the concentration of air ions in the ambient air.

The degree of ionisation is an important additional factor that, together with the chemical and physical pollution of the air, affects the human body. Circumstances in which people are exposed to increased air pollution are often associated with a sharp decrease in the concentration of light air ions, or cluster ions. Thus, human body is exposed to the summary harmful impact of air pollution and deionised environment (see table 1, examples 5 and 6). In cases where the level of air pollution is close to or slightly above the MPC and the concentration of light air ions is optimum or slightly elevated (mainly indoors when using artificial air ionisation), partial compensation for the negative effect of pollution can theoretically occur because of the positive impact of air ions (table 1, examples 8 and 9). In order to assess adequate levels of chemical pollution above the MPC and intervals that allow compensation for the harmful effects, further research is needed in the medical and hygiene field, which is currently not sufficient. For this reason, it is not advisable to use artificial ionisation in premises where people are present if the MPC of at least one air quality parameter is exceeded, therefore air purification by ionisers should be performed only when people are not present [19]. The above statements indicate that the impact compensation area can exist when the value of PM 10 is in the range from $40 \mu \mathrm{g} \cdot \mathrm{m}^{-3}$ (i.e. MPC of PM 10) to $0.1 \mathrm{mg} \cdot \mathrm{m}^{-3}$ because a stable concentration of heavy air ions at a harmful level is reached only when PM 10 amounts to $0.1 \mathrm{mg} \cdot \mathrm{m}^{-3}$.

The value of unipolarity coefficient $K$ of both light and heavy air ions is an important factor. Looking at the medical and air quality aspect, it should be $0.4 \leq K \geq 1.0$, but previous studies indicate that it often exceeds the stated value as a result of daily variations, and in places with significant atmospheric pollution the value of $K$ in the long term exceeds 1. [17], [24]

Table 1 theoretically examines various cases where $K$ is within the normal range, but it should be taken into account that elevated or reduced air ion concentration, if $K$ is above 1 , in combination with chemical and physical air pollution causes even more harm to human body.

If air pollution consists of a physical component such as PM 10 and its concentration is from $4 \cdot 10^{-5}$ to $1 \cdot 10^{-}$ ${ }^{4} \mathrm{~g} \cdot \mathrm{m}^{-3}$, it is possible to compensate for the impact of pollution by artificial air ionisation, which would facilitate air purification, besides air ions would have a positive effect on human health. In case the particular matter significantly exceeds $1 \cdot 10^{-4} \mathrm{~g} \cdot \mathrm{m}^{-3}$, the amount of heavy air ions created by the ioniser can be excessive, they cannot settle in time or stick to the walls of the premise. 
Heavy ions, inhaled in this way, get into the body and can cause specific harmful side effects (see figure $1 \mathrm{a}$ )).

If air pollution consists of a chemical component such as $\mathrm{SO}_{2}$, artificial air ionisation has a positive effect on humans only if the $\mathrm{SO}_{2}$ concentration does not raise above the MPC, which in this case is $125 \mu \mathrm{g} \cdot \mathrm{m}^{-3}$ (it depends on national legislation in each country). Where the MPC is exceeded, human body is exposed to the impact of $\mathrm{SO}_{2}$ as a harmful gas, and artificial ionisation only reinforces this effect by making the $\mathrm{SO}_{2}$ in ionised state easier to be absorbed by human body (see figure 1 b)). In a more realistic case when the MPC of both the physical and chemical pollution components is exceeded in the air, artificial air ionisation will naturally contribute to its purification, but it would not be desirable for a person to stay in such a room. In this case, it is difficult to predict the full range of interactions between pollutants and air ions and to foresee what semi and final products are being formed.

Another additional aspect is the different chemical composition of air ions of both polarities. In some studies, e.g. Patil et al., 2012, it has been found that in the process of air ion formation or artificial generation, oxygen molecules form mainly negative ions, while pollution molecules usually get a positive charge [25]. The predominance of positive air ions is in itself a negative factor for human health, but their chemical composition determines the volume of additional toxicological effects. Light air ions generated by interaction with pollution are transformed into heavy ones and their chemical composition at different stages can vary. This problem requires further in-depth research.

\section{CONCLUSIONS}

The use of air ionisers as a universal tool for purifying the indoor air and improving microclimate is still under discussion. Artificial air ionisation alone is not enough in cases where concentrations of air pollutants are significantly above the MPC. In addition to ionisation, further air purification by physical or chemical means is required. Ionisation of polluted air contributes to its purification, but this process can also generate ozone, as well as many heavy air ions with variable chemical composition, and these factors are harmful to health. The use of artificial air ionisation in premises with polluted air also requires to control the concentration of light and heavy air ions, besides the control of the chemical composition of the air is also desirable. In order to properly understand the chemical and physical transformation of air ions during the air purification process, further research under laboratory conditions is required.

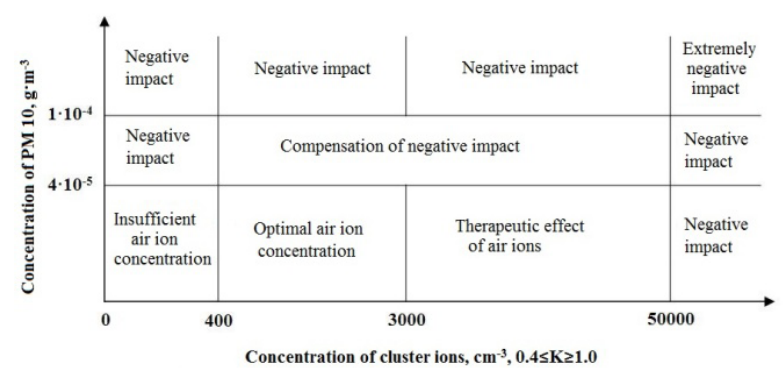

a)

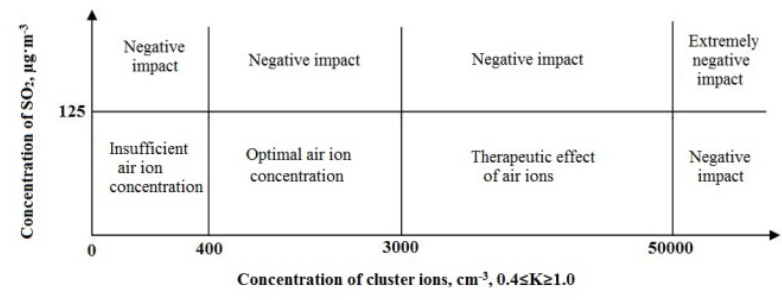

b)

Fig. 1. Area of the summary impact of atmospheric pollution and concentration of light air ions:

a) with compensation for the negative impact;

b) without compensation for the negative impact.

\section{REFERENCES}

[1] Z. Mo, Q. Fu, L. Zhang, D. Lyu, G. Mao, L. Wu, P. Xu, Z. Wang, X Pan, Z. Chen, X. Wang, X. Lou,"Acute Effects of Air Pollution on Respiratory Disease Mortalities and Outpatients in Southeastern China", Sci Rep, vol. 8, pp. 1-9, Feb., 2018.

[2] D. Kim, Z. Chen, L.F. Zhou, S.X. Huang, "Air Pollutants and Early Origins of Respiratory Diseases”, Chronic Dis. Transl. Med., vol. 4, pp.75-94, Jun. 2018

[3] S. Esposito, C. Galeone, M. Lelii, B.Longhi, B. Ascolese, L. Senatore, E. Prada, V. Montinaro, S. Malerba, M.S. Patria, N. Principi, "Impact of Air Pollution on Respiratory Diseases in Children with Recurrent Wheezing or Asthma", BMC Pulm. Med., vol. 14, Aug. 2014.

[4] X.Q. Jiang, X.D. Mei, D. Feng. "Air Pollution and Chronic Airway Diseases: What Should People Know and Do?", J. Thorac. Dis., vol. 8, pp.31-40, Jan. 2016.

[5] J.M. Deshpande, U.D Holla, "Impact of Ambient air Pollutants on the Indoor Air Quality in Mumbai“, proceedings: Indoor Air 2002, pp 623-628, 2002.

[6] J. Zhang, K.R. Smith "Indoor Air Pollution: a Global Health Concern”, British Medical Bulletin, vol. 68, pp. 209-225, 2003.

[7] J. Černecky, K. Valentova, E. Pivarčiova, P. Božek, ’Ionization Impact on the Air Cleaning Efficiency in the Interior", Measurement Science Review, vol. 15, No. 4, pp. 156-166, 2015.

[8] R. E. Priiman. O ponjatii “svezhost' vozdukha”. Uchonije zapisi Tartuskogo Gosudarstvennogo Universiteta, No. 669, pp. 115-121, 1984.

[9] A.Shiue, S.C. Hu, "Contaminant particles removal by negative air ionic cleaner in industrial mini environment for IC manufacturing processes", Building and Environment, Vol. 46, Issue 8, pp. 1537-1544, 2011.

[10] L. I. Gerasimova, Ju. A. Danilov, A. R. Jevstignejev, M. S. Machabeli, V. P. Tikhonov. "Aerojonoterapija", Kaluga, Lazernaja Akademija Nauk Rossijskoi Federaciji, pp.5-13, 1996.

[11] N. Britigan, A. Alshawa, S.A. Nizkorodov, "Quantification of Ozone Levels in Indoor Environments Generated by Ionization and Ozonolysis Air Purifiers", J. Air \& Waste Management Assoc. vol. 56, pp.601-610, 2006. 
Environment. Technology. Resources. Rezekne, Latvia Proceedings of the 12th International Scientific and Practical Conference. Volume I, 267-271

[12] Air purification, [Online]. Available: https://www.nasa.gov/ mission pages/station/research/advasc.html, (01.03.2019).

[13] Ja. Ju Reinet "O normah aerojonov v pomeschenijah" Uchonije zapisi Tartuskogo Gosudarstvennogo Universiteta, No. 648, pp.46-51, 1983.

[14] L.H. Hawkins, T. Barker, “Air Ions on Human Performance”, Ergonomics, Volume 21, Issue 4, pp. 273-278, 1978.

[15] L.H. Hawkins, "The influence of air ions, temperature and humidity on subjective well being and comfort", Journal of Environmental Psychology, Vol. 1, Issue 4, pp. 279-292, 1981.

[16] SanPin 2.2.4.1294-03 Gigienicheskije trebovanija k aerojonnomu sostavu vozdukha proizvodstvennih i obschestvennih pomeschenij, Moskva, Federalnij centr Gossanepidnadzora Minzdrava Rossiji, 2003, p.11.

[17] A. Skromulis, "Impact of Anthropogenic Pollution on Air Ion Concentration", Summary of the Doctoral Thesis, RTU Press, Riga, 2018.

[18] Schotchik aeroionov "Sapfir-3M" Rukovodstvo po ekspluataciji [Online]. Available https://ionization.ru/en/yantar-catalog/15-airion-counter-sapphire-3m.html (05.01.2019).

[19] L. N. Milova "Jonizacija vozdushnoi sredi v uslovijah promishlennogo goroda I jejo vlijanie na zdorovje naselenija (na primere goroda Lipetska)". Dissertacija na soiskanije uchonoi stepeni kandidata medicinskih nauk, Moskva, 2004.
[20] V. M. Pazinich, V. I. Chinchevich, V.F. Gagara, Ju. D. Suleko "Uchot adaptacionnikh reakcij pri gigienicheskom reglamentirovaniji aerozolei metallov v atmosphere vozdukha". Gigiena i Sanitarija, No.4, pp.4-7, 1988.

[21] L, Pirjola, P. Paasonen, D. Pfeiffer, T. Hussein, K. Hämeri, T. Koskentalo, et al. "Dispersion of particles and trace gases nearby a city highway: mobile laboratory measurements in Finland". Atmos. Environ. vol.40 pp. 867-879., 2006.

[22] A. A. Dudarev, V. I. Turubarov. Aktualnije problem gigienicheskogo normirovanija ionov v vozdukhe. Medicina truda i promishlennaja ekologija , No. 9, pp. 35-39., 2002.

[23] U. Hõrrak U. "Air Ion Mobility Spectrum at a Rural Area." Dissertationes Gophysicales Univeritatis Tartuensis, Tartu University Press, Tartu, 2001.

[24] A. Skromulis, G. Noviks, “Atmospheric Light Air Ion Concentrations and Related Meteorological Factors in Rezekne City, Latvia." Journal of Environmental Biology, vol. 4, pp. 455-462, 2012.

V.N. Patil, B.P. Patil, A. Jha, N.G. Shimpi, "Proposed Negative Ion Generator," International Journal of Applied Information Systems, Vol. 3, No.8, pp. 44-48., 2012. 